\title{
Analisis Strategi Pemasaran Industri Tenun di Desa Wisata Gamplong Kabupaten Sleman
}

\author{
Ratih Indah Sari ${ }^{1}$, Sri Rahayu Budiani ${ }^{2}$
}

Fakultas Geografi, Universitas Gadjah Mada, Yogyakarta, Indonesia ${ }^{12}$

Email Koresponden: ratihindah26@gmail.com

Diterima: November 2017 /Disetujui: Januari 2018 / Publikasi online: Maret 2018

(c) 2018 Fakultas Geografi UGM dan Ikatan Geograf Indonesia (IGI)

\begin{abstract}
Abstrak Strategi pemasaran sangat diperlukan dalam menghadapi kegiatan perdagangan yang semakin maju. Untuk itu IKM dituntut lebih inovatif agar produk yang dipasarkan tidak kalah saing dengan produk daerah lain. Penelitian ini bertujuan 1) Mengetahui faktor lingkungan internal yang berpengaruh terhadap strategi pemasaran industri tenun Gamplong, 2) Mengetahui faktor lingkungan eksternal yang berpengaruh terhadap strategi pemasaran industri tenun Gamplong, dan 3) Mengetahui sistem pemasaran yang sesuai untuk industri tenun Gamplong. Metode yang digunakan dalam penelitian ini adalah deskriptif kualitatif dimana data diperoleh dengan cara wawancara, observasi, dan dokumentasi. Wawancara dilakukan di Desa Wisata Gamplong yang merupakan sentra industri tenun di Kecamatan Moyudan. Hasil lapangan digunakan untuk analisis SWOT yang terdiri dari tabel IFAS, tabel EFAS, matriks IE, dan matriks SWOT. Hasil penelitian ini menunjukkan faktor internal yang berpengaruh berupa: kepemilikan alat secara pribadi, inovasi produk dan bahan baku, harga terjangkau, kurangnya promosi, keterbatasan modal usaha, kendala komunikasi, dan kurangnya link pemasaran. Faktor eksternal yang berpengaruh berupa: pasar luas dengan posisinya sebagai desa wisata, adanya pelatihan industri, kurangnya pengetahuan tentang inovasi, konflik internal, adanya pasar global, dan regenerasi pengrajin tenun. Strategi pemasaran yang sesuai untuk industri tenun Gamplong adalah strategi menjaga dan mempertahankan.
\end{abstract}

Kata kunci: Industri Tenun Gamplong, Analisis SWOT, Strategi Pemasaran

\begin{abstract}
Marketing strategy is needed in the face of increasingly advanced trading activities. For that IKM demanded more innovative so that the marketed products are not less competitive with other regional products. The purpose of this research are 1) to know the internal environmental factors that influence the marketing strategy of Gamplong weaving industry, 2) to know the external environmental factors that influence the marketing strategy of Gamplong weaving industry, and 3) to know the appropriate marketing system for Gamplong weaving industry. The method used in this research is descriptive qualitative where the data obtained by interview, observation, and documentation. The interview was conducted at Gamplong Tourist Village which is the center of weaving industry in Moyudan District. Field results are used for SWOT analysis consisting of IFAS table, EFAS table, IE matrix, and SWOT matrix. The results of this study indicate influential internal factors: private ownership of tools, product innovation and raw materials, affordable prices, lack of promotion, limited business capital, communication constraints, and lack of marketing links. External influencing factors include: broad market with position as tourism village, industry training, lack of knowledge about innovation, internal conflict, global market, and regeneration of weaving craftsmen. An appropriate marketing strategy for the Gamplong weaving industry is a strategy to maintain and maintain.
\end{abstract}

Keywords: Gamplong Weaving Industry, SWOT Analysis, Marketing Strategy

\section{PENDAHULUAN}

Pembangunan ekonomi suatu bangsa merupakan pilarpentingbagiterselenggaranya proses pembangunan di segala bidang. Sektor industri merupakan salah satu sektor yang berperan penting dalam pembangunan nasional. Salah satu kekhawatiran pengusaha saat ini adalah dengan adanya Masyarakat Ekonomi Asean (MEA) yang merupakan salah satu bentuk perdagangan bebas yang berada di kawasan Asia Tenggara. Untuk menghadapi MEA, negara anggota ASEAN khususnya Indonesia harus mempersiapkan diri terlebih lagi Indonesia memiliki peluang pasar terbesar di Asia Tenggara. Adanya MEA menuntut suatu industri khususnya industri kecil menengah (IKM) untuk lebih inovatif agar produk yang dipasarkan tidak kalah saing dengan produk dari negara lain (Anis dan Widiasari, 2015). Para pelaku usaha yang minim akan kreatifitas dan inovasi akan menjadi permasalahan tersendiri bagi keberlanjutan industri.

Industri tenun yang berada di Desa Wisata Gamplong, Desa Sumberrahayu, Kecamatan Moyudan merupakan salah satu IKM turun temurun yang masih mempertahankan sistem alat tenun bukan mesin (ATBM) sebagai ciri khasnya. Produk tenun yang dihasilkan berupa kain lurik, stagen, serbet, alas piring, dan berbagai produk kerajinan tenun lainnya. Keputusan untuk tetap bertahan pada ATBM padahal teknologi semakin canggih mengharuskan industri 
tenun Gamplong melakukan inovasi dalam hal lain salah satunya pada strategi pemasaran yang digunakan. Inovasi merupakan pengenalan cara baruatau kombinasi baru dari cara-cara lama dalam mentransformasi input menjadi output yang menghasilkan perubahan (Fontana, 2011).

Ciri khas yang dimiliki Desa Wisata Gamplong seharusnya mampu menjadikan desa wisata berkembang dan maju, namun pada kenyataannya lambat laun jumlah pengusaha tenun mengalami penurunan. Permasalahan lainnya adalah berubahnya status industri tenun yang dahulu merupakan pekerjaan utama masyarakat, saat ini berubah menjadi pekerjaan sampingan. Permasalahan tersebut dapat disebabkan oleh berbagai hal salah satunya adalah kesalahan dalam pemilihan strategi pemasaran. Strategi pemasaran merupakan kombinasi dari bauran pemasaran yang diterapkan oleh seorang pengusaha untuk melayani pasar (Gitosudarmo, 1994).

Strategi pemasaran yang dipilih oleh para pengusaha tentunya akan berbeda-beda hal ini dipengaruhi oleh berbagai faktor. Kesuksesan suatu industri bersaing tergantung pada penyesuaian secara dinamis terhadap lingkungan yang berubah-ubah. Perubahan tersebut ditandai oleh naik turunnya penjualan produk yang dipengaruhi oleh faktor eksternal dan internal lingkungan. Sehingga pemilihan strategi pemasaran dapat dipengaruhi oleh berbagai faktor lingkungan baik internal maupun eksternal.

Suatu strategi pemasaran harus dibuat dengan memperhatikan aspek lingkungan baik internal maupun eksternal. Sedangkan analisis SWOT merupakan suatu cara untuk menggambarkan dan mengevaluasi suatu usaha berdasarkan faktor lingkungan internal dan eksternal industri, metode ini digunakan untuk mencari strategi yang tepat yang digunakan oleh suatu industri (Christanto, 2011). Untuk itu diperlukan analisis SWOT untuk menentukan kekuatan, kelemahan, peluang, dan ancaman yang dimiliki oleh suatu industri. Hal ini didasarkan pada logika bahwa strategi pemasaran yang baik adalah dengan meminimalkan kelemahan dan ancaman serta memaksimalkan kekuatan dan peluang.

Analisis yang digunakan lebih menekankan pada pola analisis spasial. Setelah dianalisis maka akan diketahui strategi pemasaran yang tepat untuk industri tenun di wilayah ini. Industri yang didukung dengan sistem atau strategi pemasaran yang tepat akan meningkatkan produktivitas suatu industri dengan begitu penghasilan ekonomi dan kesejahteraan masyarakat juga akan meningkat. Berdasarkan uraian diatas maka penelitian ini memiliki tujuan, mengetahui faktor lingkungan internal yang berpengaruh terhadap strategi pemasaran industri tenun di Desa Wisata Gamplong, mengetahui faktor lingkungan eksternal yang berpengaruh terhadap strategi pemasaran industri tenun di Desa Wisata Gamplong dan mengetahui sistem pemasaran yang sesuai untuk industri tenun di Desa Wisata Gamplong.

\section{METODE PENELITIAN}

Jenis penelitian ini menggunakan penelitian deskriptif kualitatif. Penelitian ini dilakukan pada salah satu industri kreatif yaitu industri tenun yang berada di Padukuhan Gamplong, Desa Sumberrahayu, Kecamatan Moyudan yang meliputi 5 padukuhan, yaitu: Gamplong 1, Gamplong 2, Gamplong 3, Gamplong 4, dan Gamplong 5. Data primer diperoleh melalui observasi secara langsung, sedangkan data sekunder diperoleh dari kelurahan Desa Sumberrahayu mengenai data pemilik usaha tenun. Populasi dalam penelitian ini adalah seluruh pemilik usaha tenun di Desa Wisata Gamplong dengan jumlah 47 pengusaha. Metode sampel yang digunakan adalah metode sensus.

Proses penyusunan strategi pemasaran dilalui dengan tiga tahapan analisis, yaitu: tahap pengumpulan data, tahap analisis dengan tabel IFAS, tabel EFAS, dan matriks IE, kemudian tahap pengambilan keputusan dengan matriks SWOT. Tahap pengumpulan data dilakukan dengan proses wawancara kepada seluruh responden, melakukan observasi secara langsung, dan dokumentasi. Tujuan pertama dianalisis dengan menggunakan tabel IFAS yaitu analisis faktor lingkungan internal dimana variabel yang digunakan terdiri dari kekuatan dan kelemahan industri tenun. Tujuan kedua dianalisis dengan tabel EFAS, yaitu analisis faktor lingkungan eksternal dimana variabel yang digunakan terdiri dari peluang dan ancaman industri tenun. Tujuan ketiga dianalisi dengan menggunakan matriks IE dan matriks SWOT yang disusun berdasarkan tabel IFAS dan tabel EFAS.

Tersusunnya tabel IFAS dan EFAS akan menghasilkan skor untuk masing-masing faktor lingkungan yang berpengaruh, kemudian digunakan untuk menentukan strategi pemasaran yang tepat. Strategi pemasaran yang sesuai untuk industri tenun di Desa Wisata Gamplong dilihat dari hasil skoring faktor internal dan eksternal. Pemberian skor untuk masingmasing poin dibantu oleh ketua paguyuban yang dianggap memiliki informasi yang lebih mendalam mengenai industri tenun Gamplong. Cara yang dilakukan dengan menggunakan kuesioner.

\section{HASIL DAN PEMBAHASAN}

\section{Gambaran Umum Desa Wisata Gamplong}

Industri tenun yang berada di Desa Wisata Gamplong ini sudah ada sejak tahun 1950-an. Industri ini merupakan peningggalan masa lampau dan dikembangkan secara turun temurun. Pada awalnya produk yang dihasilkan hanya kain lurik, serbet, dan stagen dengan sasaran pemasaran hanya ke pasar-pasar tradisional. Sejak tahun 1997, produk yang dihasilkan 
dan bahan baku yang digunakan pun lebih bervariasi dengan hasil seperti alas piring, tas, tikar, dan lainnya, serta bahan baku yang digunakan berupa lidi, mendong, serat lama, dan lainnya. Salah satu ciri khas yang dimiliki oleh industri tenun di Desa Wisata Gamplong adalah proses pembuatan tenun dengan menggunakan alat tenun bukan mesin (ATBM).

Sistem pemasaran yang dilakukan oleh pengusaha tenun Gamplong didominasi oleh sistem penjualan secara langsung kepada konsumen. Wilayah pemasarannya pun meluas ke luar kota, luar jawa, hingga manca negara. Jangkauan pasar industri tenun di lingkup lokal Pulau Jawa (Gambar 1) meliputi: Yogyakarta, Bandung, Surabaya, Tasikmalaya, Madura, Kudus, Solo, dan Sragen. Sasaran terbesar ada pada Kota Yogyakarta. Sebagian besar pengusaha memasarkan produknya ke Pasar Ngijon yang merupakan pasar kecamatan di Kecamatan Moyudan dengan lokasi yang dekat dengan Desa Wisata Gamplong. Para pengrajin tenun yang memasarkan produknya di Pasar Ngijon, mereka memasarkan $100 \%$ produk yang dihasilkan ke pasar tersebut. Sasaran lainnya adalah Pasar Beringharjo yang merupakan pasar induk di Kota Yogyakarta, dengan produk yang dipasarkan rata-rata diatas 50\% dari produk yang dihasilkan.

Jangkauan pasar industri tenun Gamplong untuk lingkup nasional Indonesia (Gambar 2) meliputi: Bali, Bengkulu, Aceh, Sumatera Utara, dan Riau. Pemasaran terbesar ada pada pulau Bali, produk yang dipasarkan ke Bali 50\% dari produk yang dihasilkan. Sedangkan untuk kota-kota lainnya hanya $10-15 \%$ dari produk yang dihasilkan. Jangkauan pemasaran industri untuk lingkup internasional (Gambar 3) meliputi: Malaysia, Singapura, Belanda, Arab, Jerman, Swiss, dan Amerika. Pemasaran dalam lingkup internasional rata-rata produk yang dipasarkan hanya 10\% dari produk yang dihasilkan.

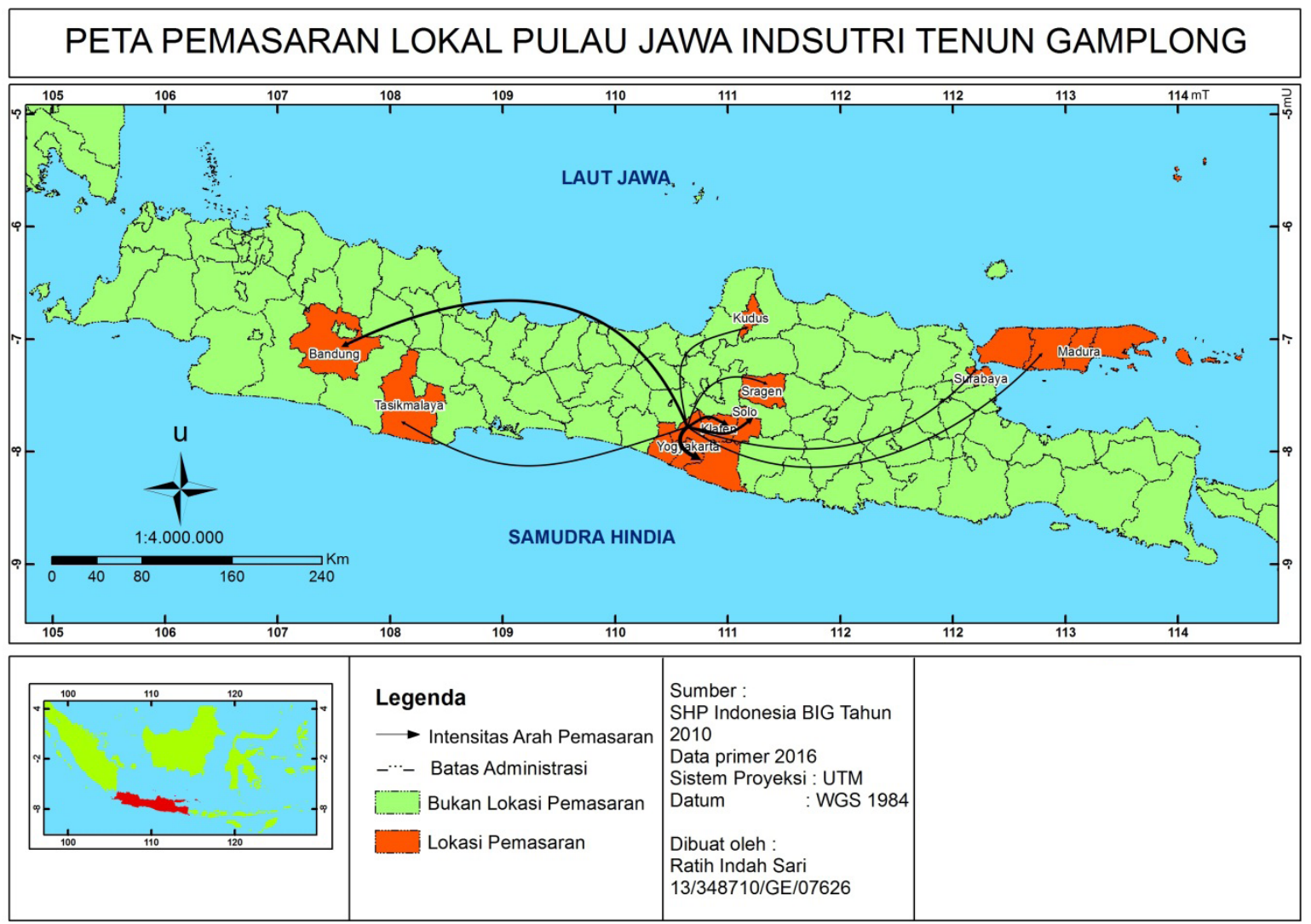

Gambar 1. Peta Pemasaran Lokal Pulau Jawa Industri Tenun Gamplong 


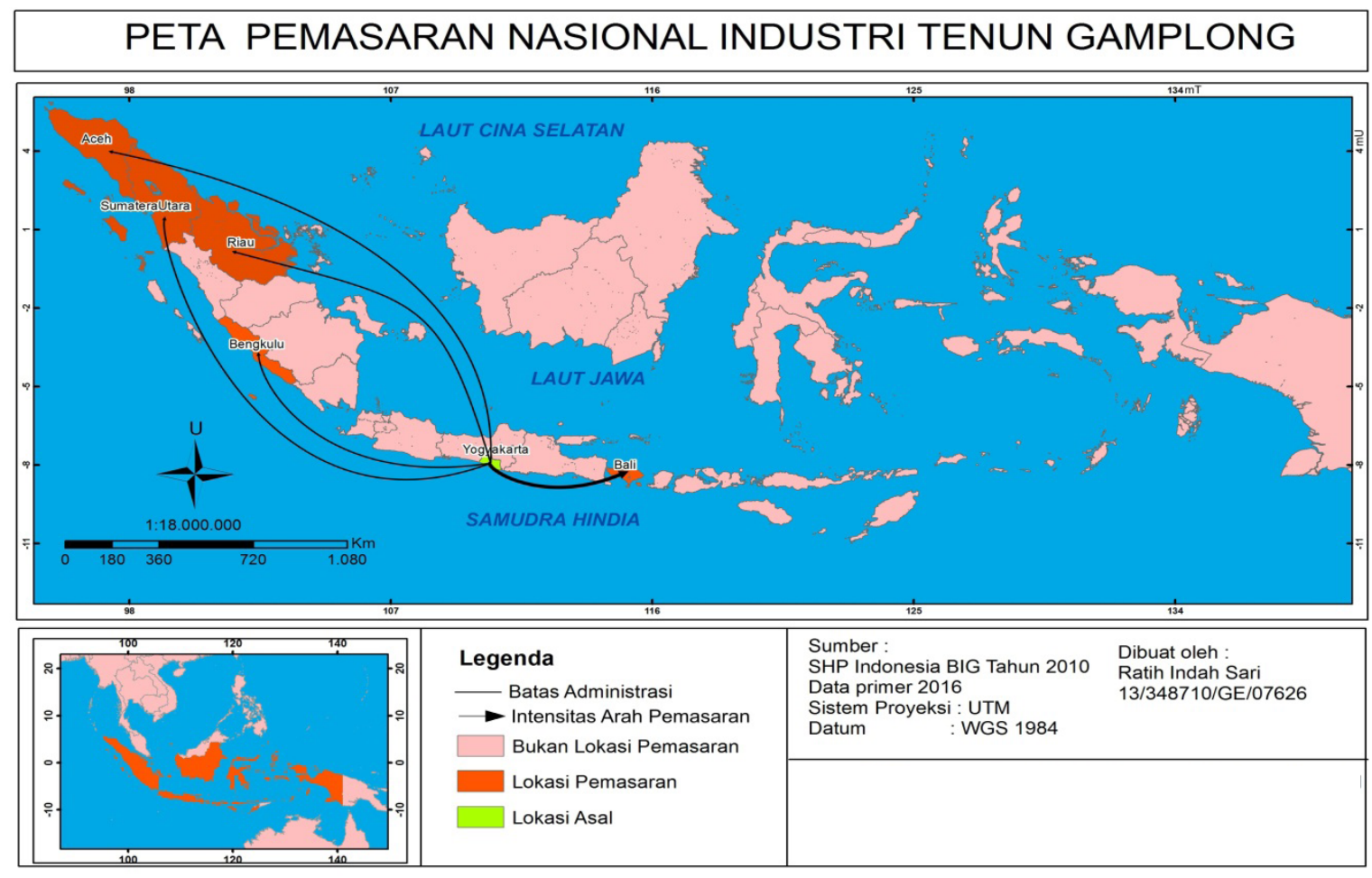

Gambar 2. Peta Pemasaran Nasional Indonesia Industri Tenun Gamplong

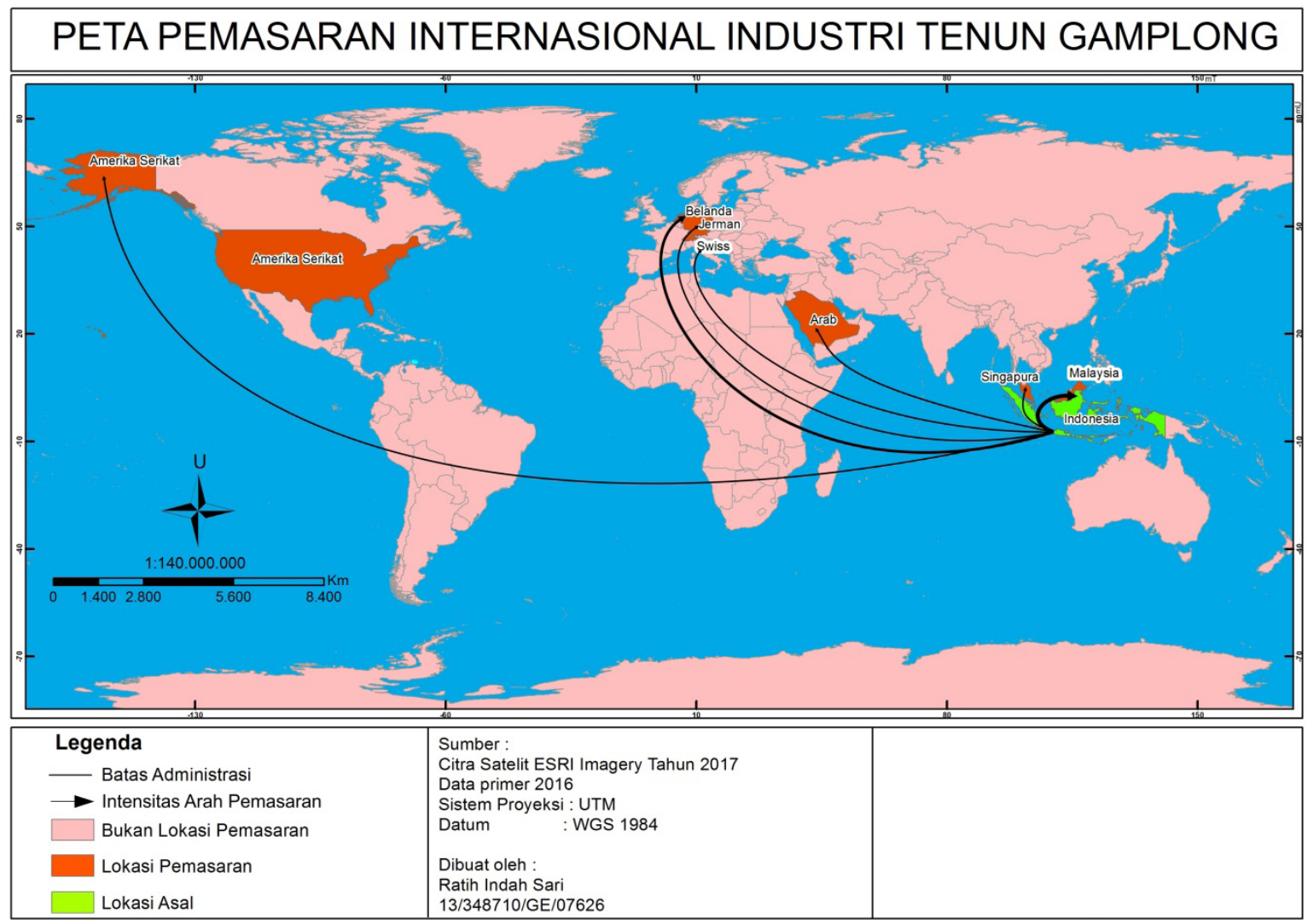

Gambar 3. Peta Pemasaran Internasional Industri Tenun Gamplong 
Kualitas produk tenun Gamplong ini cukup bagus, hal ini tergantung pada kualitas masing-masing pengusaha. Semakin tinggi skala usaha biasanya kualitas yang dihasilkan lebih bagus. Harga dari produk industri tenun Gamplong sangat terjangkau, mulai dari Rp 2.000 hingga ratusan ribu. Setiap produk memiliki harga yang berbeda tergantung dari aspek bahan baku, dan tingkat kerumitan proses pembuatan. Promosi sebagai alat komunikasi pemasaran untuk menginformasikan produk terhadap konsumen (Nurcahyo, 2016) yang dilakukan oleh pengrajin tenun dirasa kurang, ketua paguyuban mengemukakan bahwa sudah ada website mengenai industri tenun Gamplong yang dibuat oleh pemerintah, namun saat ini sudah tidak tahu bagaimana keberlanjutannya. Akses internet yang sulit di wilayah ini menjadi salah satu penghambat kegiatan promosi yang dilakukan.

Lokasiindustritenun Gamplongberadapadalokasi strategi yang mudah dijangkau dan diakses konsumen. Tidak ada hambatan terkait sarana transportasi. Sarana transportasi merupakan hal penting dalam suatu industri karena pergerakan barang dan manusia belum bisa berlangsung tanpa adanya transportasi (Silondae, 2016). Modal yang digunakan para pengusaha sebagian besar berasal dari modal sendiri. Sumber modal usaha dapat diperoleh dari modal sendiri, bantuan pemerintah, lembaga keuangan baik bank mapun lembaga keuangan non bank. Besar kecilnya modal akan berpengaruh terhadap perkembangan usaha dalam pencapaian pendapatan (Riyanto, 2011).
Bahan baku yang digunakan untuk kerajinan tenun di Gamplong terdiri dari benang, lidi, enceng gondok, dan serat alam. Tenaga kerja industri tenun Gamplong berasal dari daerah yang tidak terlalu jauh dan beberapa masih memiliki hubungan keluarga. Tenaga kerja tersebut sebagian besar berasal dari wilayah Gamplong, Bantul, dan Kulon Progo. Jumlah tenaga kerja pada setiap pengusaha tentunya berbeda. Tingginya tingkat penyerapan tenaga kerja di suatu industri dipengaruhi oleh beberapa hal, antara lain modal, jumlah produksi yang dihasilkan, dan luas cakupan pasar (Rahmat dan Budiani, 2013).

Limbah yang dihasilkan berupa limbah cair dari sisa pewarnaan produk yang nantinya dibuang langsung ke saluran pembuangan masing-masing pengusaha. Sedangkan untuk limbah padat dimusnahkan dengan cara dibakar. Namun untuk pengusaha yang hanya memproduksi stagen dan serbet tidak menghasilkan limbah. Penyuluhan dan pembinaan mengenai pengelolaan limbah pernah diadakan oleh Universitas Gadjah Mada, namun hanya sebagian kecil pengusaha yang mengikuti. Penyuluhan tersebut pun tidak rutin dilakukan.

\section{Analisis Lingkungan Internal}

Setelah faktor strategis internal suatu industri diidentifikasi, kemudian disusun tabel IFAS (Internal Strategic Factors Analysis Summary) untuk merumuskan strategi yang tepat dalam kerangka faktor kekuatan dan kelemahan industri tenun Gamplong. Tabel 1 adalah tabel IFAS industri tenun Gamplong:

Tabel 1. IFAS

\begin{tabular}{lllc}
\hline \multicolumn{1}{c}{ Faktor Internal } & $\begin{array}{c}\text { Bobot } \\
\text { Kekuatan }\end{array}$ & Rating & Skor \\
\hline Memiliki alat tenun pribadi & 0,1081081 & 3 & 0,32432432 \\
Inovasi bahan baku dan produk & 0,1081081 & 2 & 0,21621622 \\
Harga produk terjangkau & 0,0810811 & 2 & 0,16216216 \\
Lokasi strategis & 0,1081081 & 3 & 0,32432432 \\
Ramah Lingkungan & 0,1081081 & 2 & 0,21621622 \\
$\quad 0,5135135$ & & 1,24324324 \\
$\quad$ Total Kekuatan & 0,1351351 & 3 & 0,40540541 \\
$\quad 0,1081081$ & 3 & 0,32432432 \\
Kurangnya kegiatan promosi & 0,1351351 & 3 & 0,40540541 \\
Keterbatasan modal usaha & 0,1081081 & 2 & 0,21621622 \\
Kendala dalam hal komunikasi & 0,4864865 & & 1,35135135 \\
Kurangnya link pemasaran & 1,0000000 & & 2,59459459 \\
$\quad$ Total Kelemahan & & & \\
Total Bobot x skor untuk Internal Factor & & & \\
\hline Sut & & & \\
\hline
\end{tabular}

Sumber : Olah Data Lapangan, 2017 
Industri tenun di Desa Wisata Gamplong memiliki kekuatan di antaranya adalah memiliki alat tenun pribadi, adanya inovasi bahan baku dan produk, harga produk yang terjangkau, kemudahan aksesibilitas, dan ramah lingkungan. Kelemahan yang dimiliki oleh industri kerajinan tenun Gamplong diantaranya adanya kurangnya kegiatan promosi, keterbatasan modal usaha, kendala dalam hal komunikasi, dan kurangnya link pemasaran. Faktor-faktor kekuatan dan kelemahan tersebut diberi bobot dan rating yang berbeda-beda, tergantung dari tingkat pengaruhnya. Hasil perhitungan didasarkan padapertimbangan dengan ketua paguyuban industri tenun Gamplong yang memiliki umur lebih muda dibandingkan dengan pengusaha tenun lainnya dan berpendidikan sehingga akan mempermudah proses penyampaian maksud peneliti dan diharapkan hasil yang didapat lebih objektif.

Hasil analisis IFAS yang disajikan pada tabel 1. dapat diketahui bahwa skor untuk faktor internal ini sebesar 2,594 yang berarti bahwa kondisi internal industri tenun berda dalam posisi rata-rata, dimana faktor yang memiliki skor tinggi ada pada poin kurangnya kegiatan promosi dan kendala dalam hal komunikasi. Kedua hal tersebut memiliki kaitan dikarenakan kurangnya promosi yang dilakukan oleh pengusaha salah satunya disebabkan oleh sulitnya akses internet di wilayah Gamplong.
Faktor internal yang dimiliki oleh para pengusaha tenun Gamplong tentunya berbeda-beda. Beberapa faktor internal diantaranya memiliki alat tenun pribadi, harga produk terjangkau, lokasi strategis, ramah lingkungan dan kendala dalam hal komunikasi dianggap semua pengrajin mengalami hal tersebut dikarenakan masih berada dalam satu wilayah dan bahan baku yang digunakan sama. Sedangkan untuk faktor inovasi bahan baku dan produk tidak semua pengrajin melakukan tersebut, pengusaha yang dianggap memiliki inovasi adalah pengusaha dengan hasil produk lebih dari satu macam. Faktor kurangnya kegiatan promosi, pengusaha yang termasuk kurang adalah pengusaha yang tidak memiliki media sosial apapun dalam proses promosi. Faktor keterbatasan modal usaha dan yang termasuk kedalam poin tersebut adalah pengusaha yang termasuk ke dalam skala industri rumah tangga. Kemudian faktor internal yang terakhir yaitu kurangnya link pemasaran, yang termasuk kedalam poin itu adalah pengusaha yang hanya memasarkan produknya ke satu tempat tujuan

\section{Analisis Lingkungan Eksternal}

Setelah faktor strategis internal tersusun, kemudian disusun pula tabel EFAS (External Factor Analysis Summary) untuk mengetahui berbagai kemungkinan peluang dan ancaman yang dihadapi oleh industri tenun Gamplong. Tabel 2 adalah tabel EFAS industri tenun Gamplong:

Tabel 2. EFAS

\begin{tabular}{|c|c|c|c|}
\hline Faktor Eksternal & Bobot & Rating & Skor \\
\hline \multicolumn{4}{|c|}{ Peluang } \\
\hline Pasar luas dengan posisinya sebagai desa wisata & 0,167 & 4 & 0,667 \\
\hline Adanya pelatihan industri tenun & 0,125 & 3 & 0,375 \\
\hline Total Peluang & 0,292 & & 1,04 \\
\hline \multicolumn{4}{|c|}{ Ancaman } \\
\hline $\begin{array}{l}\text { Kurangnya pengetahuan masyarakat mengenai } \\
\text { pentingnya inovasi }\end{array}$ & 0,208 & 1 & 0,208 \\
\hline Terbukanya pasar global & 0,167 & 3 & 0,500 \\
\hline Konflik Internal & 0,125 & 3 & 0,375 \\
\hline Regenerasi pengrajin tenun & 0,208 & 1 & 0,208 \\
\hline Total Ancaman & 0,708 & & 1,083 \\
\hline Total Bobot x skor untuk External Factor & 1,000 & & 2,125 \\
\hline
\end{tabular}

Sumber: Olah Data Lapangan, 2017

Industri tenun di Desa Wisata Gamplong memiliki peluang antara lain pasar yang luas dengan posisi sebagai desa wisata serta adanya pelatihan untuk industri tenun. Sedangkan ancaman yang dimiliki industri tenun antara lain kurangnya pengetahuan masyarakat mengenai pentingnya inovasi, terbukanya pasar global, adanya konflik internal, dan regenerasi pengrajin tenun. Berbagai faktor peluang dan ancaman memiliki bobot dan rating yang berbeda tergantung dari pengaruhnya terhadap perkembangan industri 
tenun Gamplong. Penentuan skor dalam analisis EFAS juga ditentukan oleh peneliti dengan berdiskusi bersama ketua paguyuban industri tenun Gamplong. Hasil analisis EFAS menunjukkan skor 2,125 yang berarti kondisi eksternal industri tenun Gamplong berada dalam posisi rata-rata, dimana faktor yang paling dominan ada pada poin pasar yang luas dengan posisinya sebagai desa wisata. Hal ini berarti gelar desa wisata tersebut akan bermanfaat dan mempunyai pengaruh yang besar bagi perkembangan industri tenun Gamplong apabila dimanfaatkan dengan benar. Dengan adanya desa wisata, masyarakat tidak hanya menjual produk tenun yang dihasilkan tetapi juga mendapatkan sumber pendapatan lain dari paket wisata yang ditawarkan, seperti adanya kursus tenun. Paket wisata tersebut juga dapat menjadi salah satu alternatif promosi produk tenun Gamplong.

Faktor eksternal yang dimiliki oleh setiap pengusaha memiliki kondisi yang berbeda-beda. Seluruh pengusaha memiliki peluang antara lain pasar yang luas dengan posisi sebagai desa wisata. Untuk faktor peluang adanya pelatihan industri tenun, tidak semua pengusaha memiliki peluang tersebut, yang termasuk kedalam poin tersebut adalah pengusaha yang pernah mengikuti pelatihan. Seluruh pengusaha tenun Gamplong memiliki ancaman terhadap terbukanya pasar global, konflik internal, dan regenerasi pengrajin tenun. Sedangkan untuk faktor ancaman kurangnya pengetahuan masyarakat mengenai pentingnya inovasi, tidak semua pengusaha memiliki ancaman tersebut. Pengusaha yang termasuk kedalamnya adalah pengusaha yang tidak mengetahui perlunya inovasi untuk keberlanjutan industri tenun.

\section{Matriks Internal-Eksternal (IE)}

Penilaian terhadap faktor internal dan eksternal yang dimiliki oleh industri tenun Gamplong dapat diperoleh total skor yang merupakan hasil perkalian bobot dengan rating. Industri tenun Gamplong memperoleh total skor 2,59 untuk faktor internal, sedangkan untuk faktor eksternal memperoleh total skor sebesar 2,125. Tahap selanjutnya berdasarkan total skor yang diperoleh dapat digunakan untuk melihat posisi industri untuk menerapkan strategi yang sesuai dengan kondisi industri tenun Gamplong saat ini, dengan memasukkan total skor kedalam matriks internal dan eksternal pada tabel 3 berikut:

Tabel 3. Matriks Internal-Eksternal (IE)

IFAS $\quad$ TINGGI $(3-4) \quad$ SEDANG $(2-3) \quad$ RENDAH (1 - 2)

TINGGI $(3-4)$

$\operatorname{SEDANG}(2-3)$

RENDAH $(1-2)$

I
PERTUMBUHAN

IV STABILITAS

VII
II

PERTUMBUHAN

$\mathrm{V}$

PERTUMBUHAN

STABILITAS

VIII

PERTUMBUHAN
III

PENCIUTAN

VI

PENCIUTAN

IX LIKUIDASI

Sumber: Olah Data Lapangan, 2017

Hasil analisis matriks IE, didapat skor IFAS sebesar 2,594 dan EFAS sebesar 2,125 maka industri tenun Gamplong berada pada sel yang telah diarsir yaitu sel V. Hal ini berarti strategi yang sesuai dengan industri tenun Gamplong adalah strategi pertumbuhan melalui integrasi horizontal dan stabilitas. Pertumbuhan melalui integrasi horizontal adalah kegiatan perluasan pasar dengan membangun di lokasi lain dan meningkatkan jenis produk (Rangkuti, 2008). Menurut David (2009) posisi perusahaan yang masuk ke dalam sel $\mathrm{V}$ dapat ditangani melalui strategi menjaga dan mempertahankan, penetrasi pasar dan pengembangan produk. Dimana pada faktanya memang industri tenun Gamplong sedang berada pada fase pertumbuhan membangun kembali kejayaan menjadi sentra industri tenun. Sehingga strategi yang sesuai adalah strategi stabilitas dengan menjaga dan mempertahankan agar tidak kehilangan profit dengan fokus kegiatan memperluas pasar dan pengembangan produk. Hal ini juga didasarkan pada permasalahan yang ada saat ini yaitu minimnya inovasi yang dilakukan oleh pengusaha tenun Gamplong dan kurangnya link pemasaran.

\section{Matriks SWOT}

Setelah melakukan analisis lingkungan eksternal dan lingkungan internal maka dapat dirumuskan kedalam analisis SWOT yang menggambarkan setiap 
kekuatan, kelemahan, peluang, dan ancaman dari industri tenun Gamplong. Berdasarkan hasil analisis didapatkan alternatif strategi yang dapat diambil oleh para pengusaha tenun dalam menghadapi persaingan yang semakin kompetitif. Tabel 4 . berikut adalah hasil analisis strategi pemasaran yang tepat untuk industri tenun Gamplong:

Tabel 4. Matriks SWOT

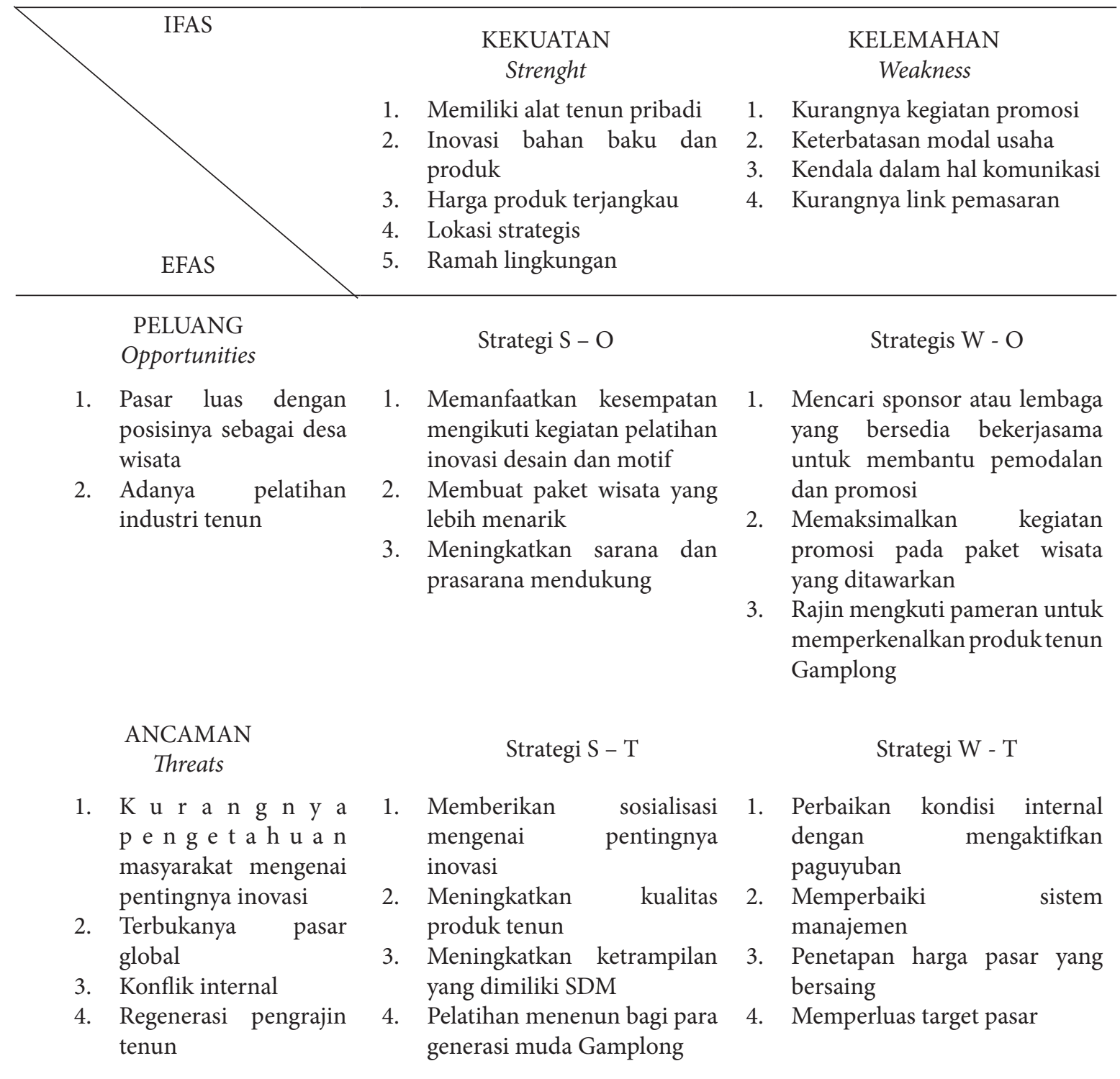

Sumber: Olah Data Lapangan, 2017

Strategi S-O merupakan strategi yang dirumuskan dengan menggunakan seluruh kekuatan dalam memanfaatkan peluang sebesar-besarnya. Berdasarkan kedua aspek tersebut strategi yang dapat diterapkan oleh industri tenun Gamplong adalah memanfaatkan kesempatan mengikuti kegiatan pelatihan inovasi desain dan motif. Dengan adanya pelatihan tersebut diharapkan dapat meningkatkan daya tarik produk sehingga akan meningkatkan permintaan pasar. Kegiatan menenun juga dapat dibuat paket wisata yang lebih menarik. Paket wisata dapat digunakan sebagai kegiatan untuk menarik konsumen, khususnya para wisatawan. Paket wisata dapat dikemas secara lebih menarik lagi dengan menawarkan berbagai kegiatan yang khas dengan desa wisata Gamplong, dan memperbanyak kegiatan yang berhubugan dengan tenun. Kegiatan wisata tersebut dapat didukung dengan peningkatan sarana dan prasaran. Sarana dan prasarana yang dimaksud seperti showroom, kamar mandi umum, homestay, dan lain sebagainya.

Strategi S-T dirumuskan dengan menerapkan kekuatan yang dimiliki oleh industri tenun Gamplong untuk mengatasi ancaman yang mungkin dapat dihadapi oleh industri tenun Gamplong. Strategi tersebut antara 
lain memberikan sosialisasi mengenai pentingnya inovasi. Menurut Arnisita (2015) pengetahuan masyarakat tentang inovasi kerajinan tenun bukan hanya berasal dari jenjang pendidikan saja, tetapi dari sosialisasi dan pelatihan-pelatihan. Sosialisasi tersebut diharapkan dapat menyadarkan masyarakat untuk terus melakukan inovasi. Inovasi tersebut penting untuk meningkatkan daya saing. Pelatihan tersebut dapat meningkatkan ketrampilan yang dimiliki oleh para pekerja. Peningkatan ketrampilan yang dimiliki oleh pekerja dan inovasi yang dilakukan akan dapat menguasai pasar dan berdaya saing tinggi apabila didukung dengan peningkatan kualitas produk. Selain itu diadakan pelatihan menenun bagi para generasi muda Gamplong agar tetap ingin melestarikan warisan sejarah tersebut.

StrategiW-Oditerapkanberdasarkan pemanfaatan peluangyangada dengan cara meminimalkan kelemahan yang ada. Strategi yang dapat digunakan industri tenun Gamplong adalah rajin mengikuti pameran untuk memperkenalkan produk tenun Gamplong. Apabila tidak ada ajakan dari pemerintah untuk mengadakan pameran maka para pengusaha tenun harus mempunyai inisiatif untuk mencari sendiri kegiatan pameran yang dapat diikuti. Dalam berbagai pameran yang diikuti dapat digunakan sebagai ajang mencari sponsor atau lembaga yang bersedia bekerjasama untuk membantu pemodalan dan promosi. Keuntungan yang didapatkan apabila memiliki sponsor adalah semakin luasnya jaringan pemasaran yang berdampak pada peningkatan permintaan produk. Selain dalam kegiatan pameran promosi dapat dilakukan pada kegiatan wisata yang ditawarkan. Promosi yang dikemas kedalam paket wisata tersebut diharapkan dapat memberikan kesan yang baik kepada para pengunjung sehingga para pengunjung dapat menceritakan apa yang mereka dapatkan ketika berwisata kepada masyarakat luas sekitarnya agar mengunjungi Desa Wisata Gamplong.

Strategi W-T diterapkan dengan meminimalkan kelemahan yang ada untuk menghindari ancaman. Strategi yang dapat diterapkan adalah perbaikan kondisi internal dengan mengaktifkan paguyuban. Dengan adanya paguyuban diharapkan dapat mempermudah segalanya seperti penyampaian informasi mengenai adanya pelatihan, melancarkan kegiatan promosi. Aktifnya peguyuban tersebut dapat mengatasi dan meminimalisir adanya konflik internal yang terjadi dikarenakan apapun yang menadi keputusan harus diselesaikan dengan musyawarah seperti dengan menetapkan harga pasar. Satu sama lain pengusaha harus memiliki harga pasar yang sama. Paguyuban yang ada akan membantu para pengusaha dalam memasarkan produk tenun khususnya untuk pengusaha skala rumah tangga yang rata-rata sudah berusia lanjut. Bantuan pemasaran tersebut dapat memperbaiki sistem manajemen keuangan pengusaha tenun sehingga kekuarangan modal usaha dapat diatasi. Selain itu dengan adanya paguyuban dapat memperluas target pasar.

Strategi yang dihasilkan dalam matriks SWOT memberikan beberapa alternatif strategi yang dapat digunakan. Secara umum strategi-strategi tersebut tidak dapat diwujudkan secara mandiri oleh para pengusaha, perlu dukungan dan bantuan dari berbagai pihak. Langkah yang dapat diambil oleh para pengusaha adalah dengan mengaktifkan lagi paguyuban tenun Gamplong, kemudian menggalang dukungan pemerintah maupun swasta untuk dapat membantu dalam kegiatan promosi untuk mengembangkan dan memajukan industri tenun Gamplong.

\section{KESIMPULAN}

Kesimpulan yang dapat diambil dari penelitian ini adalah Faktor lingkungan internal yang berpengaruh terhadap strategi pemasaran industri tenun Gamplong terdiri dari kekuatan dan kelemahan yang dimiliki. Kekuatan industri tenun Gamplong antara lain kepemilikanalattenun pribadi,inovasiprodukdanbahan baku yang dilakukan, harga produk yang terjangkau, lokasi industri yang strategis, dan ramah lingkungan. Sedangkan kelemahan industri tenun Gamplong antara lain kurangnya kegiatan promosi, keterbatasan modal usaha, kendala dalam hal komunikasi, dan kurangnya link pemasaran.

Faktor lingkungan eksternal yang berpengaruh terhadap strategi pemasaran industri tenun Gamplong terdiri dari peluang dan ancaman yang dimiliki. Peluang industri tenun Gamplong antara lain Gamplong pasar yang luas dengan posisinya sebagai desa wisata dan adanya pelatihan industri tenun. Sedangkan ancaman industri tenun Gamplong antara lain kurangnya pengetahuan masyarakat mengenai pentingnya inovasi, konflik internal yang terjadi, terbukanya pasar global, dan regenerasi pengrajin tenun.

Strategi pemasaran yang sesuai untuk industri tenun Gamplong adalah strategi menjaga dan mempertahankan agar tidak kehilangan profit dengan fokus kegiatan memperluas pasar dan pengembangan produk.

\section{DAFTAR PUSTAKA}

Anis, M., \& Widiasari, N. (2015). Analisis Kesiapan Industri Kreatif Menghadapi Masyarakat Ekonomi Asean. Simposium Nasional Teknologi Terapan, Universitas Muhammadiyah Surakarta.

Christanto, Joko. (2011). Membangun Daya Saing Daerah melalui Penciptaan Kompetisi Inti Daerah. Yogyakarta. Deepublish.

David, Fred R. (2009). Strategic Management: Manajemen Strategis Konsep. Jakarta. Salemba Empat. 
Fontana, Avanti. (2011). Innovate We Can!. Bekasi. Cipta Inovasi Sejahtera.

Gitosudarmo, Indriyo. (1994). Manajemen Pemasaran. Yogyakarta. BPFE.

Nurcahyo, Fandry. (2016). Pengaruh Bauran Pemasaran Terhadap Volume Penjualan pada Restoran McDonald's Delta Plaza Surabaya. Jurnal Ilmu dan Riset Manajemen, Vol V-No 4, Hal 1-17.

Rahmat, O.M., \& Budiani, S.R (2013). Pengaruh Keberadaan Industri Kerajinan Perak Terhadap Penyerapan Tenaga Kerja dan Pendapatan Pekerja di Kecamatan Kotagede Yogyakarta. Jurnal Bumi Indonesia, Vol II- No 2, Hal 68-77.

Rangkuti, Freddy. (2008). Analisis SWOT Teknik Membedah Kasus Bisnis. Jakarta. PT Gramedia Pustaka Utama.

Riyanto, Bambang. (1996). Pembelanjaan Perusahaan. Yogyakarta. BPFE.

Silondae, Sutami. (2016). Keterkaitan Jalur Transportasi dan Interaksi Ekonomi Kabupaten Konawe Utara dengan Kabupaten/Kota Sekitarnya. Jurnal Progres Ekonomi Pembangunan, Vol I-No 1, Hal 1-7. 